\title{
Black Women's Activism in Brazil: Black Genocide, Anti-Blackness and racial Apartheid
}

\author{
Ativismo de mulheres Negras no Brasil: genocidio \\ negro, anti-negritude e apartheid racial
}

KENNETH M. WiLLIAMSON (D)

\section{Resumo}

Este artigo enfoca as mudanças na militância das mulheres negras, particularmente em Salvador, Bahia, Brasil, de 1995-2015, comparando duas marchas nacionais. Organizações negras em todo o país se uniram para organizar uma marcha nacional em Brasília, capital do país, em Novembro de 1995. Vinte anos depois, em Novembro de 2015, as mulheres negras organizaram uma marcha nacional para abordar a interseção do racismo e do sexismo. Durante esses vinte anos, militantes negras trabalharam incansavelmente contra o genocídio negro, o anti-negritude e o apartheid racial no Brasil, e as mulheres negras estiveram na linha de frente dessas lutas. A interseccionalidade de raça, classe e gênero foi e permanece crítica para a militância das mulheres negras e a produção do conhecimento e da pesquisa. 0 artigo examina as mudanças na militância no movimento negro ao longo de vinte anos que marcaram o crescimento das organizações e redes de mulheres negras.

Palavras-chave: Militância das Mulheres Negras Brasileiras, Anti-negritude e Genocídio Negro, Interseccionalidade.

\section{Abstract:}

This article focuses on changes in Black women's activism, particularly in Salvador, Bahia, Brazil, from 1995-2015, by comparing two national marches. Black organizations throughout the country came together to organize a national march in national's capital Brasilia in November 1995. Twenty years later in November 2015 , Black women organized a national march to address the intersection of racism and sexism. During those twenty years, Black activists worked tirelessly against

\footnotetext{
a Kennesaw State University, Doutor em Antropologia. E-mail: kwill254@kennesaw.edu
} 
Black genocide, anti-Blackness and racial apartheid in Brazil, and Black women stood on the frontlines of these struggles. The intersectionality of race, class, and gender were and remain critical to the activism of Black women and to the production of research and knowledge. The paper examines the changes activism in the Black movement over twenty years that marked the growth on Black women's organizations and networks.

Keywords: Black Brazilian Women's Activism, Anti-Blackness and Black Genocide, Intersectionality.

\section{Resumen}

Este artículo se centra en los cambios en el activismo de las mujeres negras, particularmente en Salvador, Bahía, Brasil, de 1995 a 2015, comparando dos marchas nacionales. Las organizaciones negras de todo el país se unieron para organizar una marcha nacional en la capital del país, Brasilia, en noviembre de 1995. Veinte años después, en noviembre de 2015, las mujeres negras organizaron una marcha nacional para abordar la intersección del racismo y el sexismo. Durante esos veinte años, los activistas negros trabajaron incansablemente contra el genocidio negro, la lucha contra la negritud y el apartheid racial en Brasil, y las mujeres negras estuvieron en la primera línea de estas luchas. La interseccionalidad de raza, clase y género fue y sigue siendo fundamental para el activismo de las mujeres negras y para la producción de investigación y conocimiento. El documento examina los cambios en el activismo del movimiento negro durante veinte años que marcaron el crecimiento de las organizaciones $y$ redes de mujeres negras.

Palabras clave: activismo de las mujeres negras brasileñas, anti-negritud y genocidio negro, interseccionalidad.

\section{Introduction}

Recent scholarship on race in Brazil argued for a move away from concepts of racism and racial discrimination towards concepts of anti-blackness and Black Genocide to more accurately describe the systems that lead to early Black death (Rocha 2012, 2018, Santos 2012,2013, Smith 2016a, Vargas 2010, 2020). Anti-Blackness and Black Genocide include the state sponsored killing of Black people by police as seen in Brazil, the United States and other parts of the African Diaspora, as well as the systems of police surveillance and mass incarceration. Additionally, there are more widespread and endemic ways of structuring early Black death including through poverty, unemployment, underemployment, poor health care, high maternal mortality, and health disparities; since modernity, the social, economic and 
political marginalization of Black people across the African Diaspora created premature death for Black people.

The recent scholarship on anti-Blackness and Black Genocide extends the work of Black activists who, in the 1950s, argued in the United Nations that systematic racism and white supremacy amounted to the genocide of Black people and crimes against humanity (Civil Rights Congress 1970). Similarly, in the 1950s, proof of Black Genocide was the direct police killings of Black people, as well as economic genocide, unemployment, high death rate through disease, and high child and infant mortality rates. The proof continues to present day; In the United States in 2017, Black Americans' life expectancy was 3.6 years less that of white Americans (Kochanek, Murphy, Xu, Arias 2019). The focus on anti-Blackness and Black Genocide moves from multi-faceted racism, which can encompass several racial groups, towards the systematic early death of Black people in African Diaspora operating over centuries.

Harrison articulated similar phenomena of Black Genocide and Anti-Blackness on a global scale through her conceptual use on Global Apartheid (2002, 2004). The concept of Apartheid focuses of differential outcomes in life expectancy due to rising inequality of access to wealth. For Harrison apartheid had been foundational to modernity since the beginning of the transatlantic slave trade and continues through existing processes (1995). The work on Global Apartheid, Anti-Blackness and Black Genocide is present in the growing work on Black Brazilian women's activism, intersectionality and resistance (Caldwell 2007, 2017, Lopez 2011, Pacheco 2008, 2013, Perry 2013, Reis 2007, Rocha 2012 2018, Santos 2012 2013, Williamson 2015).

The gendered natured of Global Apartheid, Black Genocide and Anti-Blackness can be found in the foundational work of Black Brazilian feminist activist scholars, such as Beatriz Nascimento, Lélia Gonzalez, Sueli Carneiro and Luiza Bairros. While their work remains vastly underappreciated in Black feminist discourse, they were the intellectual, political and activist founders of Black feminist practice within the Black Movement in Brazil. Lélia Gonzalez and Luiza Bairros were instrumental in the foundation of the Unified Black Movement. Sueli Carneiro was the founder and director of Geledés, a Black women's organization. MNU and Geledés are two central organizations in the history of the contemporary Black Movement in Brazil. Beatriz Nascimento, who was also a member of the Unified Black Movement, documented her participation in the Black Movement through $\mathrm{h}$ her film, Ori. All four were also scholars who provided critical understanding of Black women's intersectional experiences in Brazil (Bairros 1999; Carneiro 2011, Gonzalez and Hasenbalg 1982, Smith 2016b)

This article expands upon the current literature by Black female activists' experiences in two national marches, one in 1995 (Zumbi 300 Years) and the other in 2015 (National Black Women's March). These two events highlight changes in the actions of Black women activists. They detail and highlight how Black activists experienced intersectionality within and outside antiracist movements, and how they developed multiple Black women's organizations and networks to address Anti-Blackness and Black Genocide.

\section{History of Black Movement in Brazil}

Black resistance to racism and genocide in Brazil has a long and storied history. Part of the struggle of the Black movement has been to popularize that history within and outside of Brazil. The lineage of Black activism and resistance begins during slavery, most notably in armed resistance in the thousands of quilombos, the most famous of which was Palmares (Anderson 1996). There were also slave revolts, like the Revolt of the Malês, as well as the quotidian resistance to slavery. (Butler 1998, Reis 1993). For example, Damasceno elucidated 


\section{Black Women's Activism in Brazil: Black Genocide, Anti-Blackness and racial Apartheid}

how Black women resisted slavery through petitioning for freedom through the court system in place like Feira de Santana, Bahia (2019).

Black resistance in Brazil continued post- abolition throughout the $20^{\text {th }}$ century through quilombos, the establishment of Black samba schools and newspapers, the formation of the political party Frente Negra, the Black Experimental Theatre (TEN), Blocos Afro, the Unified Black Movement (MNU), Black Organizations, Houses of Candomblé, and numerous other Black organizations; scholars documented the tireless work of the black movement in Brazil to address racism and racial discrimination (Andrews 1991, 1992; Bairros 1996: Butler 1998; Caldwell 2007, 2017; Carneiro 2011; Covin 2006; Gonzalez 1985; Gonzalez and Hasenbalg 1982; Hanchard 1994, 1999; Movimento Negro Unificado 1988, Nascimento 1979, Silva 1994).

In the early 1970s in Bahia, the primary vehicle for activism was through the promotion of culture, which the military dictatorship supported as a means to promote tourism; activists formed and supported the African centered carnival group Ilê Ayiê to communicate about racial discrimination, inequality, and black pride. In the latter 1970s, the Unified Black Movement Against Racial Discrimination (MNUCDR) formed nationally, with chapters in most states, and brought together various activists across Brazil. Racial discrimination was not the only issue, as the groups organized and protested against poverty, police brutality, the dictatorship, inadequate education, unemployment, hunger, and discrimination. After 1982, the United Black Movement Against Racial Discrimination shortened its name to MNU, many of its members separated to form their own organizations (Covin 1990, 1996, 2006, Gonzalez 1982, Gonzales and Hasenbalg 1985, Movimento Negro Unificado 1988). From the 1980s onward, the number of organizations represented under the banner of the black movement have multiplied and diversified. The dispersion and multiplication may expand the term "movement" beyond its central focus. But in terms of anti-racism message and resistance, the strands run though most organizations, implicitly if not explicitly. The diversity includes Houses of Candomblé, Capoeira schools, organizations directly involved in electoral politics like MNU and UNEGRO, as well as various other music-centered groups like blocos afros, Rap, Reggae and Hip Hop groups. Black movement organizations form coalitions with labor, student, feminist, indigenous and urban movements organizations, and black movement activists have various and long participation with these other movements. The impact of the black movement, from the inclusion of anti-racist language in leftist political parties and unions, to the formation of government-sponsored agencies to deal with racial issues and black culture, has been undeniable. Black Movement organizations and their alliances with labor unions, Indigenous people, student movements and leftists' political parties organize large protests and press for justice, equality and change within Brazilian society.

\section{Zumbi 300 Years: November 20, 1995 March}

On November 20, 1995, Black activists from across Brazil gathered together for national march in Brasilia, the nation's capital. Activist and organizations collaborated to organize bus caravans, for which they had spent months raising funds to charter. They marched, sang, and reunited with black activists from all over Brazil in the nation's capital 
for the 300th anniversary of the rebirth the Black Brazilian hero Zumbi. Rescuing African heritage and celebration resistance to racism and oppression was always a priority, even more so with the celebration for Brazil's first black national hero.

Zumbi was part of the Black Movements racial project in Brazil to change the racial frame in Brazil and challenge the frames of racial democracy and whitening (Winant 1994). They worked to establish the anniversary of the rebirth of Zumbi on November 20 as the national day of black consciousness and challenge the myth of Brazil as a racial democracy, which was commemorated on May $13^{\text {th }}$ by the final decree to end slavery by Princess Isabel in 1888. The Black movement was critical in diminishing the strength of racial democracy as an interpretive, representative, and explanatory racial project.

Activists from a myriad of political and cultural organizations united to mixed gender organizations united to organize the march. MNU, with chapters in most states, was instrumental in coordinating the march. From the founding of the Unified Black Movement Against Racial Discrimination in 1978, many women were involved in mixed gender organizations; everyone shared concerns about racism, a desire to change public debates about race and racism, and changes to socially, politically and economically to address systemic racial discrimination. These organizations included more politically oriented organizations such as MNU and UNEGRO, cultural organizations such as blocos afros (the most well know being Ilê Ayiê and Oodum), and religious organizations including many terreiros de Candomlê (McCallum 2007, Williamson 2015). Within many of the mixed gender originations, such as MNU, there were women's groups that formed to specifically address issues that affected Black women.

The 1995 march celebrated the end of racial democracy within the Brazil and articulated the move towards addressing contemporary and ongoing racial discrimination within the Brazil. The broad-based organizing and collaboration with other progressive groups, such as labor unions and left leaning political parties, laid the groundwork for the substantial changes to public policy to address racial discrimination.

Due to their ceaseless and tireless work of Black activists in Brazil, the twenty years that followed the 1995 march witnessed some of the greatest progress to address contemporary racial discrimination. From 2002-2014, the expansion of affirmative action in Brazilian universities admissions allowed poor, Black Brazilian to attend universities, which had been a near impossibility. In 2003, the teaching of Afro-Brazilian history became mandatory in public schools. In 2010, the Statue of Racial Equality passed. In 2014, the Domestic Workers' Law guaranteed social security, paid holidays, overtime pay and improved working conditions for domestic workers, the majority of whom were Black and lacked benefits and protections from employers.

Yet and still, following the 1995 march and the twenty years afterward, there was a continued critique and frustration with the Black movement from Black female activists, who argued for public policy to address the intersectional ways oppression operates. These female activists, along with newer activist to the Black movement, were central to organizing the next national march on November 15, 2015.

\section{Black Women's March Against Racism and Violence and for Well Being: November 18,2015}

On November 18, 2015 Black women from various parts of Brazil came together for a national march in the capital city Brasilia. The march was the result of years of activism by Black women. In Bahia, Black women formed the Black Women's Network. They held meetings throughout the state of Bahia, in cities and small towns, with local groups of Black women to discuss the issues confronting them. They discussed the death of their children at the hands of police, the struggle of quilombos for their struggles for existence, territory and 


\section{Black Women's Activism in Brazil: Black Genocide, Anti-Blackness and racial Apartheid}

self-determination. They discussed the high rate of domestic violence and homicide that Black women experience. They discussed the impact of Eurocentric beauty standards of Black women and the misrepresentations and distortions of Black women in media. They discussed the high maternal rate among Black women. They discussed the fight for religious freedom for practitioners of Candomblé. They wanted to end workplace discrimination and harassment. They argued for better health care They were a diverse group of Black women-urban and rural, from a range of education levels, and diverse religiously-who came together for a common purpose to highlight the joint oppression of racism and sexism that threatened their existence and livelihoods and propose solutions.

Through the Black Women's Network, Black women organized and shared information through social media. The Black Women's Network of Bahia joined together with Black women from all over Brazil in the march to Brasilia and presented their list of demands to then president Dilma Rousseff.

Dramatic progress in public policy to address systemic racism was achieved during the time when the Worker's Party won four consecutive presidential elections from 20022014. Increasingly however, Black women found that while the public policy, as well as their male activists in the movement, did not address issues that affected them as Black and female, and generally poor.

Ana Cláudia Lemos Pacheco, a former member of the Unified Black Movement (MNU) and of the women's group of Unified Black Movement (MNU), demonstrated in her research that Black female activist suffered personally and politically because of their commitment to Black feminism (2008). Pacheco (2008) and Bairros (1999) articulated the struggles of Black female activists in mixed gender organizations, particularly the patriarchal and misogyny of Black male activists.

Whereas previously black female activists pressed discussions with mixed gender organizations, there has been a noticeable shift more recently towards focusing of issues and organizing related to black women specifically. Black male activists in the last presidential election in 2014, pulled black movement organizations to support the Workers' Party unconditionally, angering many black women who argued that Black organizations needed to remain independent. The women felt that it was a mistake for MNU and other organizations made; the leadership went into political parties and the organizations gained influence through these elected leaders and the organization worked to keep them in political office. The organizations also stood as legacies for these politicians, as the Steve Biko Institute does for the City Councilman Silvio Humberto. The underhanded way in which black men seized control over several organizations further fed the disenchantment of black women.

Black women have articulated public policies, within and outside of Black mixed gender organizations, to address the intersectional oppression of Black women; Luiza Bairros, Lélia Gonzalez, Beatriz Nascimento and Sueli Carneiro emphasized intersectionality in looking at the implementation and effectiveness of public policies to address racism and sexism. The trajectory of Black Women's activism in Brazil shifted out of a longstanding frustration with Black men, who oftentimes reproduce patriarchal and sexist practices in mixed gender organizations.

Rev. Caminhos da Educação: diálogos, culturas e diversidades, Teresina, v. 2, n. 3, p. 172-182, set./dez. 2020 
The shift in activism has been dramatic with the formation of the Black Women's Network in Bahia. The campaign started using social media to disseminate ideas and information pertaining to black women. Meetings were organized in the Salvador in towns in the interior of the state where women throughout the state travelled to join the conversation. They organized local marches in the cities and towns, and promoted the idea of a national march in Brasilia.

While the 1995 and the 2015 marches were both extremely emotional achievements for activists and the result of years of dedication and sacrifice, the 2015 march highlighted the intersectionality of Black women in Brazil nationally and internationally. It also encapsulated a change for the women activists who participated in the 1995 march as many focused solely on building networks with other Black women, supporting Black women their campaigns for local political office, and grassroots organizing of Black women in urban and rural communities. Many of the women who participated in the 1995 march no longer participated in organizations with men. As Crenshaw (1991) noted that Black women often find themselves in antiracist movements and organizations that fail to address sexism and sexual violence and perpetuate patriarchy and misogyny, and the older Black women activists decided that they only wanted to focus on Black women's issues and political empowerment. The older activists were joined by energetic groups of younger activists, who benefitted from the spaces created by more senior activists.

\section{Discussion:}

The last decade brought the growth and spread of Black Women's Activism in Bahia and other regions of Brazil, as seen in the growth of groups such as the Black Women's Network. Additionally, the enthusiastic reception of scholar activists such as Kimberlé Crenshaw and Angela Davis, reaffirmed the central of Black Women's intersectional struggles against racism, sexism and poverty. However electoral power remains elusive and the sharp conservative turn in national elections of Brazil in 2018 created greater fear of reprisal by the national government. Previously, conservative governments unified progressive groups, anti-racist, workers, students, feminist, and indigenous movements and unions in opposition to state policies. While resistance remains strong, the divide seems more permanent between Black women's groups and other Black organizations. However, the strength of Black Women's Activism continues to grow despite severe challenges.

Today, the intersectional differences in the movement are more apparent, visible and activated. Particularly, there has been tremendous growth in Black Women's Activism. Newer groups like the Black Women's Network and Odara, complement long established Black Women's organizations like Geledes, the Black Women's Forum and Criola. The incredible well outpouring of support for Angela Davis and Kimberlé Crenshaw was the fruit of years of Black women's activism. Black female activists were familiar with the works of Crenshaw, Davis, bell hooks as well as their own Lélia Gonzalez and Beatriz Nascimento. And the new generation of scholars work on Black Genocide, Anti-Blackness and Global Apartheid continue inform and inflect the work of activists in Brazil, many of whom are also scholar.

The shift in activism has been dramatic with the formation of the Black Women's Network in Bahia. The campaign started using social media to disseminate ideas and information pertaining to black women. Meetings were organized in the Salvador in towns in the interior of the state where women throughout the state travelled to join the conversation. They organized local marches in the cities and towns, and promoted the idea of a national march in Brasilia.

But other serious issues remained. Between 2003-2013, the Map of Violence indicate a $54.2 \%$ increase in the homicide rate for Black women in Brazil, while the homicide rate for

Rev. Caminhos da Educação: diálogos, culturas e diversidades, Teresina, v. 2, n. 3, p. 172-182, set./dez. 2020 


\section{Black Women's Activism in Brazil: Black Genocide, Anti-Blackness and racial Apartheid}

white women slightly declined over the same period. While state sponsored murder affected Black women as well as Black men, as seen in murder of Marielle Franco, the majority of murders of Black females in Brazil were due to intimate partner violence. Even as tremendous strides were made in addressing racial discrimination, the intersectionality of black women meant that public policy that addressed either race or gender overlooked them.

While the challenges facing Black people today are significant, the ground has shifted substantially from the 1990s. There are many more Black students in colleges and universities, which was previously nearly impossible for Black students who went to public schools. The organizations are activists are more diverse, yet stronger in their diversity. Significant challenged remain. Black women activists marched on Brasilia and presented their list of demands to prudent Dilma Rousseff, who was subsequently impeached and removed from office; afterwards a conservative government openly advocated and promoted Black Genocide. Acknowledging these challenges should not cloud the fact that Black Brazilian activists changed the country between the 1995 and 2015 marches. Indeed, the stage is set for the next generation of activists to take the stage, with hope and courage, continue to mobilize, organize, and lead the next movement to the address intersectional systemic issues that affect Black women.

References

Anderson, Robert Nelson. The Quilombo of Palmares: A New Overview of a Maroon State in Seventeenth-Century Brazil. Journal of Latin American Studies. 28(3):545-566. 1996.

Andrews, George Reid. Black Political Protest in São Paulo, 1888-1898. Journal of Latin American Studies. 24: 147-171. 1992.

Andrews, George Reid. Blacks and Whites in Sao Paulo, Brazil, 1888-1988. Madison: University of Wisconsin Press. 1991.

Bairros, Luiza. Orfeu e Poder: Uma Perspective Afro-Americana Sobre a Política Racial No Brasil. Afro-Ásia. 17:173-186. 1996.

Bairros, Luiza. Lembrando Lélia Gonzalez. Afro-Ásia 23, Salvador. 1999.

Butler, Kim D. Freedoms Given, Freedoms Won: Afro-Brazilians in Post-Abolition São Paulo and Salvador. New Brunswick, NJ: Rutgers University Press. 1998.

Caldwell, Kia Lilly. Negras in Brazil: Re-envisioning Black Women, Citizenship, and the Politics of Identity. New Brunswick, NJ: Rutgers University Press. 2007. 
Caldwell, Kia Lilly. Health Equity in Brazil: Intersections of Gender, Race, and Policy. Champaign: University of Illinois Press. 2017.

Carneiro, Sueli. Racismo, Sexismo, e Desigualdade no Brasil. São Paulo: Selo Negro Edicões. 2011.

Civil Rights Congress. We Charge Genocide; the Historic Petition to the United Nations for Relief from a Crime of the United States Government against the Negro People. New York: International Publishers. 1970.

Covin, David. The Unified Black Movement in Brazil, 1978-2002. McFarland \& Company: Jefferson, NC. 2006.

Crenshaw, Kimberlé. Mapping the Margins: Intersectionality, Identity Politics, and Violence against Women of Color. Stanford Law Review 43 (6): 1241-1299. 1991.

Damasceno, Karine Texeira. Para Serem Donas De Si: Mulheres Negras Lutando em Familia. (Feira De Santana, Bahia, 1871-1888). 2019. 244, PhD Dissertação. Doutorado Historia. Universidade Federal da Bahia. 2019.

Gonzalez, Lelia. The Unified Black Movement. A New Stage in Political Mobilization. In Pierre-Michel Fontaine, ed. Race, Class, and Power in Brazil. Los Angeles: Center for AfroAmerican Studies, University of California. 1985. Pp. 120-135.

Gonzalez, Lelia, and Carlos Hasenbalg. Lugar do Negro. Rio de Janeiro: Editora Zero Limitida. 1982.

Hanchard, Michael. Orpheus and Power: The Movimento Negro of Rio de Janeiro and Sao Paulo, Brazil 1945-1988. Princeton: Princeton University Press. 1994.

Hanchard, Michael, ed. Racial Politics in Contemporary Brazil. Durham: Duke University Press. 1999.

Harrison, Faye V. The Persistent Power of 'Race' in the Cultural and Political Economy of Racism. Annual Review of Anthropology. 24:47-74. 1995.

Harrison, Faye V. Global Apartheid, Foreign Policy, and Human Rights. Souls: A Critical Journal of Black Politics, Culture, and Society 4(3): 48-68. 2002.

Harrison, Faye V. Global Apartheid, Environmental Degradation, And Women's Activism for Sustainable Well-Being: A Conceptual and Theoretical Overview. Urban Anthropology and Studies of Cultural Systems and World Economic Development. 33:1: 1-35. 2004.

Kochanek KD, Murphy SL, Xu JQ, Arias E. Deaths: Final data for 2017. National Vital Statistics Reports. 68(9): 1-77. Hyattsville, MD: National Center for Health Statistics. 2019. https://www.cdc.gov/nchs/data/nvsr/nvsr68/nvsr68 09-508.pdf

López Laura Cecilia. Uma Análise das Políticas de Enfrentamento ao HIV/Aids na Perspectiva da Interseccionalidade de Raça e Gênero. Saude e Sociedade. 20(3): 590-603. 2011. 
McCallum, Cecilia. Women out of Place? A Micro-Historical Perspective on the Black Feminist Movement in Salvador da Bahia, Brazil. Journal of Latin American Studies 39 (1): 5580. 2007.

Movimento Negro Unificado. 1978-1988: 10 Anos de Luta Contra o Racismo. Sao Paulo: Confraria do Livro. 1988.

Nascimento, Abdias do. Brazil: Mixture or Massacre? Essays in the Genocide of a Black People. Dover, MA: The Majority Press. 1979.

Pacheco, Ana Claudia Lemos. Branca Para Casar, Mulata Para F ..., Negra Para Trabalhar': Escoblas Afetivas E Significados De Solidão Entre Mulheres Negras Em Salvador, Babia. 2008. 317. $\mathrm{PhD}$ Dissertação. Doutorado em Ciências Sociais. Universidade Estadual de Campinas. 2008.

Pacheco, Ana Claudia Lemos. Mulher Negra: Afetividade E Solidão. Salvador: EDUFBA. 2013.

Perry, Keisha-Khan Y. Black Women against the Land Grab: The Fight for Racial Justice in Brazil. Minneapolis, MN: University of Minnesota Press. 2013.

Reis, João José. Slave Rebellion in Brazil: The Muslim Uprising of 1835 in Babia. Arthur Brakel, trans. Baltimore: John Hopkins University Press. 1993.

Reis, Vilma. Black Brazilian Women and the Lula Administration. NACLA Report on the Americas 40 (2): 38-41. 2007.

Rocha, Luciane de Oliveira. Black Mothers' Experiences of Violence in Rio De Janeiro. Cultural Dynamics 24(1): 59-73. 2012.

Rocha, Luciane de Oliveira. Maternidad Indignada: Reflexiones Sobre El Activismo de Las Madres Negras y El Uso de Las Emociones En Investigación Activista. Anthropologica 36 (41): 35-56. 2018.

Santos, Sônia Beatriz dos. Controlling Black Women's Reproductive Health Rights: An Impetus to Black Women's Collective Organizing. Cultural Dynamics 24 (1): 13-30. 2012.

Santos, Sônia Beatriz dos . Famílias Negras, Desigualdades, Saúde e Saneamento Básico No Brasil. Tempus Actas de Saúde Coletiva 7 (2): 41-53. 2013.

Silva, Maria Auxliadôra Gonçalves da. Encontros e Desencontros de Um Movimento Negro. Brasília: Fundação Cultural Palmares. 1994. 
Smith, Christen Anne. Afro-Paradise Blackness, Violence, and Performance in Brazil. Champaign: University of Illinois Press. 2016a.

Smith, Christen Anne. Towards a Black Feminist Model of Black Atlantic Liberation: Remembering Beatriz Nascimento. Meridians: feminism, race, transnationalism 14(2): 71-87. 2016b.

Vargas, Joao H. Costa. Never Meant to Survive: Genocide and Utopias in Black Diaspora Communities. Lanham: Rowman \& Littlefield. 2010.

Vargas, João H Costa. Racismo Não Dá Conta: Antinegritude, a Dinâmica Ontológica e Social Definidora Da Modernidade. Em Pauta. 45(18): 16-26. 2020.

Williamson, Kenneth. Some Things Cannot Be Separated: Intersectionality in the Lives of Black Women Activists in Salvador, Brazil. African and Black Diaspora: An International Journal 8(1):86-101. 2015.

Winant, Howard. Racial Conditions: Politics, Theory, Conditions. Minneapolis: University of Minnesota Press. 1994. 